\title{
DIREITOS HEREDITÁRIOS DO COMPANHEIRO
}

\author{
Thaís Cesario Nunes da Cunha ${ }^{1}$
}

\section{INTRODUÇÃO}

As mudanças que ocorrem na lei e nos posicionamentos doutrinários e jurisprudenciais são inegáveis no contexto jurídico pátrio, no que tange ao direito das sucessões.

Conforme os ensinamentos de Carlos Silveira Noronha:" "as mudanças que se encontram abrigadas na ordem sucessória, mais que puras e simples inovações 'per se' desse ramo da civilística moderna e pós-moderna, constituem reflexos de situações fáticas ocorrentes no complexo social e de compartimentos da própria ordem jurídica, [...] que ocorrem diante da necessidade de proteger a família e o patrimônio que a ela deve permanecer unido [...]”.
E diante dessas variações, pretende-se apresentar, com o estudo ora proposto, as questões mais atuais e complexas dos direitos hereditários do companheiro, oferecendo evidências e até mesmo ponderações desse instituto do direito das sucessões que suscita tantas divergências.

\section{A união estável como entidade familiar a ser protegida pelo estado}

No Brasil, a união estável como forma originária de família, passível de proteção do Estado, remonta apenas a 1988 em nosso ordenamento jurídico, quando da promulgação da Constituição da República, que em seu art. 226, $\S 3^{\circ}$, dispõe que:

1 Mestranda em Direito. PPGDir/UFRGS.

2 NORONHA, Carlos Silveira. Reflexões doutrinárias acerca do direito das sucessões. In: . (Org.). As novas perspectivas do direito das sucessões em tempos de modernidade e pós-modernidade. Porto Alegre: Sulina, 2011, p. 13. 
"Para efeito de proteção do Estado, é reconhecida a união estável entre o homem e a mulher como entidade familiar, devendo a lei facilitar sua conversão em casamento". ${ }^{3}$

Entretanto, referida relação jurídica não é moderna, posto que desde o direito romano é possível constatar a existência de concubinato, termo que era utilizado para representar qualquer união afetiva entre um homem e uma mulher, que fosse isenta das formalidades do casamento. No nosso país, o concubinato já encontrava previsão nas Ordenações Filipinas.

A jurisprudência em época anterior à vigência da Constituição da República ignorava e desconhecia a união estável, negando-lhe qualquer efeito. Nessa época, referida relação jurídica era denominada de concubinato, o qual, com o passar do tempo, passou a ser equiparado à sociedade de fato e tratado pelo Direito das Obrigações. ${ }^{4}$ Com o advento da Súmula 380 do $\mathrm{STF}^{5}$, a partilha de bens entre companheiros passou a se tornar possível, embora fosse necessário comprovar o esforço comum na formação do patrimônio. Cumprindo afirmar que a estrutura desse instituto foi construída e consagrada pouco a pouco pelos pretórios, quando provocados para deliberar a respeito dos mais variados casos concretos.

O Código Civil de 1916 não fez qualquer menção quanto à união estável, nem proibindo, nem regulamentando; porém, tratou a respeito do concubinato ${ }^{6}$, conferindo diversas

3 De acordo com Veloso, considera-se importante esclarecer que "a Constituição, ao sinalizar que a lei deve facilitar a conversão da união estável em casamento, não está estabelecendo hierarquia, precedência ou preferência entre essas duas formas de constituição de família. [...] O que ela quer, simplesmente, é que, se os conviventes resolverem casar, que esse objetivo seja facilitado, dispensando-se os que já vivem juntos, em união estável, como entidade familiar, de algumas exigências que são prescritas para os que não exibem tal condição”. Ainda, conforme VELOSO, “casamento e união estável são entidades familiares, de idêntica altura, de igual importância e com a mesma dignidade" (VELOSO, Zeno. Direito hereditário do cônjuge e do companheiro. São Paulo: Editora Saraiva, 2010, p. 159 e 164).

4 FERRIANE, Luciana de Paula Assis. Sucessão do companheiro. São Paulo: Editora Saraiva, 2010, p. 25.

5 O Supremo Tribunal Federal em 1963 editou a Súmula n 380 nos seguintes termos: "Comprovada a existência de sociedade de fato entre os concubinos é cabível a dissolução judicial, com a partilha do patrimônio adquirido pelo esforço comum”.

6 Atualmente, com o avanço do Direito, é possível constatar uma diferenciação entre concubinato e união estável. O art. 1.727 do Código Civil de 2002 dispõe que: “As relações não eventuais entre o homem e a mulher, impedidos de casar, constituem con- 
cubinato". Portanto, convém ressaltar que ao analisarmos o termo "concubinato" acima mencionado, leia-se concubinato impuro, visto que o concubinato puro reflete em seu âmago todos os caracteres da união estável, os quais, de forma acertada, podem ser equiparados (apesar de que a palavra "concubinato" é utilizada indistintamente por alguns doutrinadores, como, por exemplo, Orlando Gomes. - GOMES, Orlando. Direito de família. 12. ed. Rev. e atual. por Humberto Theodoro Júnior. Rio de Janeiro: Forense, 2000. p. 46). O concubinato impuro é aquele que não pode ser convertido em casamento; que não enseja união estável, entre um homem e uma mulher, porque pelo menos um deles (conviventes) não apresenta estado civil compatível ou apresenta qualquer impedimento dirimente para o casamento. Álvaro Villaça de Azevedo, por sua vez, ao apresentar seu anteprojeto de lei (Art. 20, seção II), conceituou o concubinato impuro como uma relação adulterina - quando paralelo ao casamento - e como desleal - quando em concomitância com outro concubinato. Considera-se que o concubinato impuro é constituído pela união adulterina, incestuosa, desleal e que apresenta impedimento para o casamento. Por outro lado, o concubinato puro é definido como a união duradoura entre solteiros, separados judicialmente, divorciados, viúvos, incluindo ainda, os separados de fato. De acordo com o art. 1.723, §1, do Código Civil de 2002: “A união estável não se constituirá se ocorrerem os impedimentos do art. 1.521; não se aplicando a incidência do inciso VI no caso de a pessoa casada se achar separada de fato ou judicialmente".

Conforme preceitua Kümpel: "o concubinato puro não desprestigia o casamento e, por isso, vem conferido de direitos de família, enquanto o concubinato impuro afronta a família e a fidelidade indispensável a ela, não recebendo proteção ou estímulo à sua manutenção". Entretanto, cumpre ressaltar que o Tribunal de Justiça do Rio Grande do Sul já decidiu que o concubinato pode ser protegido e amparado pelo Direito de Família (KÜMPEL, Vitor. Concubinato impuro. São Paulo: Complexo Jurídico Damásio de Jesus, jul. 2001. Disponível em: <www.damasio.com.br/novo/html/frame_artigos.htm>. Acesso em: 09 jul. 2011). Veja-se: CONCUBINATO E CASAMENTO. DUPLICIDADE DE UNIÃO AFETIVA. EFEITOS. Caso em que se reconhece que o 'de cujus' vivia concomitantemente em estado de união estável com a apelante (inclusive com filiação) e casamento com a apelada. Caso concreto em que, em face da realidade das vidas, se reconhece direito à concubina a $25 \%$ dos bens adquiridos na constância do concubinato. DERAM PARCIAL PROVIMENTO. (SEGREDO DE JUSTIÇA) TRIBUNAL DE JUSTIÇA DO RS. Apelação Cível No 70004306197, Oitava Câmara Cível, Tribunal de Justiça do RS, Relator: Rui Portanova, Julgado em 27/02/2003. O Relator em seu voto dispôs o seguinte: [...] é possível dizer que o novo sistema do direito de família se assenta em três institutos: um, preferencial e longamente tratado, o casamento; outro, reconhecido e sinteticamente previsto, a união estável; e um terceiro, residual aberto para as apreciações caso a caso, o concubinato. Vale a pena salientar que, da forma como está redigido o art. 1.727, o novo Código não proibiu o concubinato. Fosse interesse do legislador proibir ou evitar expressamente qualquer efeito diria claramente "em caso de relação não eventuais entre o homem e a mulher, impedidos de casar, é defeso retirar efeito patrimonial". Não foi isso que fez o novo Código Civil. Ele disse que, em face de relações caracterizadas por "relações" (afetivas, por evidente), "não even- 
restrições, como a anulação do ato de doação de bens à concubina e o direito de a esposa reaver tais bens doados.

O prestígio e a previsão na legislação dos direitos sucessórios para os companheiros sobreviventes vieram a ocorrer somente em 1994, com a Lei n. 8.971, e depois em 1996, com a Lei n. 9.278, que abordaram exclusivamente a respeito da união estável. A primeira, consagrando os direitos dos companheiros à sucessão, aos alimentos e à partilha de bens; a segunda, modificando alguns pressupostos da união estável tratou acerca de regime de bens, direito a alimentos e direito de habitação.

Finalmente, com a edição do Código Civil de 2002, a união estável passou a ser prevista no direito codificado, tanto no direito de família ${ }^{7}$, como no direito sucessório. ${ }^{8}$ Ressaltando que, com a entrada em vigor do referido diploma legal, o direito sucessório dos companheiros foi reduzido se comparado à legislação anterior, o que representou uma involução ao nosso ordenamento jurídico.

É preciso convir que as mudanças nos costumes sociais contribuíram para que esse assunto, que era um tabu, fosse aceito como uma união responsável, entre pessoas de sexos opostos que não adotam o casamento como forma de constituição de família. Nesse sentido, é possível averiguar que a união estável ganhou contorno jurídico, com o passar do tempo, na medida em que o Direito se viu obrigado a abordar um fato, que embora considerado pela sociedade primitiva como moralmente reprovável, era existente, e cada vez mais presente no contexto social moderno e pós-moderno. ${ }^{9}$

tuais” (contínuas, duradouras), “entre homem e mulher impedidos de casar” (como, por exemplo, aqueles que já são casados), estas relações “constituem” um novo instituto de direito de família que chamamos “concubinato”. Em suma, o novo Código: a) diferente do que acontecia no Código Civil antigo, reconheceu a existência de uma realidade que tem aportado nos Tribunais, qual seja, (repetindo os termos da lei) "relações não eventuais entre o homem e a mulher, impedidos de casar”; b) deu um nome para essas relações: concubinato; c) não previu efeitos, mas, atento a uma de suas diretrizes fundamentais, deixou para o juiz decidir em cada caso concreto os efeitos que entender de justiça. [...] (grifou-se).

7 Arts. 1.723 a 1.726 do Código Civil de 2002.

8 Art. 1.790 do Código Civil de 2002.

9 KÜMPEL, Vitor. Concubinato impuro. São Paulo: Complexo Jurídico Damásio de Jesus, jul. 2001. Disponível em: <www.damasio.com.br/novo/html/frame_artigos. htm>. Acesso em: 09 jun. 2011. 
2 DIREITOS HEREDITÁRIOS DOS COMPANHEIROS EM FACE DO CÓDIGO CIVIL DE 2002

As polêmicas envolvidas na sucessão decorrente da união estável possuem fulcro no tratamento diferenciado que recebem o viúvo e o companheiro supérstite, aquele com bem mais vantagens do que esse frente ao ordenamento jurídico pátrio; pois, embora o Código Civil de 2002 represente avanços quanto aos direitos hereditários dos cônjuges, no que tange aos direitos dos companheiros vislumbra-se um possível retrocesso, em total desconsideração aos direitos conquistados nas leis especiais de 1994 e de 1996.

\subsection{Da comprovação da} existência de união estável à época do falecimento de um dos conviventes

Inicialmente, cumpre destacar que o estado de companheiro - que persistia à época do falecimento de um dos conviventes - deve ser demonstrado, ${ }^{10}$ com a morte do autor da herança, para que os respectivos efeitos jurídicos possam ser conferidos. Caso a convivência dos companheiros não exista mais à época do falecimento de um deles, extingue-se o direito sucessório, pois não há mais união estável. ${ }^{11}$ Por outro lado, convém mencionar que aos cônjuges é desnecessária a persistência do casamento à época do falecimento de um dos seus partícipes visto que a separação de fato só produz efeitos no direito sucessório se superior a dois anos.

\subsection{O companheiro sobrevivente: meeiro}

Faz-se necessário ressaltar ainda, antes de adentrar no cerne da análise dos direitos hereditários do companheiro, que o óbito gera duas consequências, tanto na esfera do direito de família como na esfera do direito das sucessões. No direito de família, a morte de um dos conviventes gera não só a extinção da união estável, mas opera a cessação da relação pa-

10 Caso os demais herdeiros não aceitem a habilitação do companheiro no inventário, esse terá que ingressar com uma ação (autônoma) de reconhecimento de união estável, para que se comprove a existência e o período dessa união.

11 Art. 1.723 do Código Civil de 2002. É reconhecida como entidade familiar a união estável entre o homem e a mulher, configurada na convivência pública, contínua e duradoura e estabelecida com o objetivo de constituição de família. (grifou-se). Nesse sentido, ver Zeno Veloso. op. cit., p. 166. 
trimonial entre os conviventes, à qual se aplica, no que couber, o regime da comunhão parcial de bens ${ }^{12}$, salvo contrato escrito pelos companheiros. ${ }^{13}$ Dessa forma, se adquiridos bens onerosos na constância da união, o companheiro(a) retira sua meação ${ }^{14} \mathrm{do}$ patrimônio comum, visto que possui a qualidade de coproprietário do de cujus. E, no direito das sucessões, com o falecimento do companheiro, surge a herança, que nada mais é do que o patrimônio do de cujus transmitido aos herdeiros e ao convivente sobrevivente em concorrência com os descendentes, ascendentes e parentes. ${ }^{15}$
A vigente lei civil silencia a respeito da meação ao companheiro; porém, não se pode deixar de apreciá-la, sob pena de causar prejuízo e injustiça a esse que é dono de sua parte ideal, antes da abertura da sucessão.

\subsection{0 companheiro sobrevivente:herdeiro necessário}

O companheiro sobrevivente não integra a ordem de vocação hereditária exposta no art. $1.829^{16}$ do Código Civil de 2002, assim como também

12 Para Cahali, na união estável há regime patrimonial e não regime de bens, por esse ser privativo do casamento. Ele considera que na união estável "a regra era de condomínio sobre os bens adquiridos a título oneroso na constância da convivência, diferentemente, embora superficialmente, do regime da comunhão parcial, onde se comunicam, por exemplo, os bens adquiridos por fato eventual” (CAHALI, Francisco José; HIRONAKA, Giselda Maria Fernandes Novaes. Curso avançado de direito civil. 3. ed. São Paulo: Editora Revista dos Tribunais, 2007, p. 178).

13 Art. 1.725 do Código Civil de 2002. Na união estável, salvo contrato escrito entre os companheiros, aplica-se às relações patrimoniais, no que couber, o regime da comunhão parcial de bens.

14 Para Diniz, "A meação é oriunda de uma relação condominial existente em vida dos cônjuges" (DINIZ, Maria Helena. Curso de direito civil brasileiro: direito das sucessões. 21. ed. rev. e atual. de acordo com a reforma do CPC. v. 6. São Paulo: Saraiva, 2007, p. 123).

15 DINIZ, op. cit., p. 123.

16 Art. 1.829 do Código Civil de 2002. A sucessão legítima defere-se na ordem seguinte: I - aos descendentes, em concorrência com o cônjuge sobrevivente, salvo se casado este com o falecido no regime da comunhão universal, ou no da separação obrigatória de bens (art. 1.640, parágrafo único); ou se, no regime da comunhão parcial, o autor da herança não houver deixado bens particulares; II - aos ascendentes, em concorrência com o cônjuge; III - ao cônjuge sobrevivente; IV - aos colaterais. 
não está arrolado como herdeiro necessário no art. $1.845^{17}$ da Lei Civil atual; porém, por força do art. 1.790 do referido diploma legal, deve ser tratado como herdeiro necessário ${ }^{18}$, pois, caso contrário, estar-se-ia negando o próprio dispositivo.

Diante do acima exposto, é importante destacar que o art. $1.850^{19}$ também não faz menção à exclusão desse sucessor, como ocorre para os herdeiros colaterais, ou seja, para os herdeiros facultativos. Em outras palavras, não é possível dizer que o testador pode dispor de seu patrimônio sem contemplar o companheiro para que esse seja excluído da sucessão. Dessa forma, o fato de o companheiro supérstite não integrar o rol do art. 1.845 não é o melhor argumento, nem é fator determinante, para não considerá-lo herdeiro necessário.

Por outro lado, Maria Helena Diniz $\mathrm{z}^{20}$ considera o convivente um herdeiro especial, em seus argumentos diz que: “[...] o companheiro supérstite não é herdeiro necessário, nem tem direto à legítima, mas participa da sucessão do de cujus, na qualidade de sucessor regular, sendo herdeiro sui generis [...]”. Além disso, ela entende que o companheiro sobrevivente pode ser excluído da sucessão, caso o autor da herança assim disponha em testamento, visto que aquele possui direito somente à meação dos bens adquiridos à título oneroso no decorrer da união. $^{21}$

Nesse sentido é o entendimento também de Francisco Cahali, que além de dizer que o companheiro supérstite não é herdeiro necessário por deixar de integrar o rol do art. 1.845 do Código Civil de 2002, menciona que isso se dá também pelo fato de que a união estável não foi comparada ao casamento pela Constituição Federal, ou seja, o companheiro não faz parte da sucessão como se casado fosse. ${ }^{22}$

Pois bem, traçados alguns apontamentos acerca do companheiro ser meeiro e herdeiro necessário, merece considerável atenção o polêmico

17 Art. 1.845 do Código Civil de 2002. São herdeiros necessários os descendentes, os ascendentes e o cônjuge.

18 Os herdeiros necessários não podem ser excluídos da herança por ato de última vontade do de cujus, a lei confere a eles a legítima.

19 Art. 1.850 do Código Civil de 2002. Para excluir da sucessão os herdeiros colaterais, basta que o testador disponha de seu patrimônio sem os contemplar.

20 DINIZ, op. cit., p. 142.

21 DINIZ, op. cit., p. 148.

22 CAHALI; HIRONAKA. op. cit., p. 181. 
art. 1.790 do Código Civil de 2002, visto que é sobremaneira criticado e comentado pela doutrina e jurisprudência brasileira.

\section{O POLÊMICO ART. 1.790 DO CÓDIGO CIVIL DE 2002}

$\mathrm{O}$ art. 1.790 do Código Civil de 2002 é sobremaneira criticado e comentado. Está previsto no capítulo intitulado "Disposições Gerais”, embora devesse estar regulado no capítulo que versa a respeito da ordem de vocação hereditária. Está disposto nos seguintes termos:

Art. 1.790. A companheira ou o companheiro participará da sucessão do outro, quanto aos bens adquiridos onerosamente na vigência da união estável, nas condições seguintes:

I - se concorrer com filhos comuns, terá direito a uma quota equivalente à que por lei for atribuída ao filho; II - se concorrer com descendentes só do autor da herança, tocar-lhe-á a metade do que couber a cada um daqueles;

III - se concorrer com outros parentes sucessíveis, terá direito a um terço da herança;

IV - não havendo parentes sucessíveis, terá direito à totalidade da herança.
À análise da redação do art. 1.790 do Código Civil de 2002 verificase a impropriedade na referência: "companheira" ou "companheiro", visto que bastaria a expressão "companheiro” para referir-se aos direitos do homem e da mulher em união estável. ${ }^{23}$

Além disso, é possível vislumbrar que o caput do dispositivo em comento preceitua que o companheiro participará da sucessão do convivente que falecer quanto aos bens adquiridos onerosamente na constância da união estável, excluindo os adquiridos antes do início da convivência e a título gratuito, como doação e herança, que serão transmitidos em sua íntegra para os descendentes, ascendentes ou parentes.

Ressalta-se ainda o equívoco na letra da lei no que toca aos termos utilizados para os descendentes do autor da herança. Ora se fala em filhos (art. 1.790, I, do Código Civil), ora se fala em descendentes (art. 1.790, II, do Código Civil). Em razão disso, é preciso fazer notar que no inciso I também incide as hipóteses em que estão presentes outros descendentes comuns, como neto, bisneto, conforme o Enunciado 266 CJF/STJ, aprovado na III Jornada de Direito Civil,

23 OLIVEIRA, Euclides. Direito de herança. A nova ordem da sucessão. 2. ed. São Paulo: Saraiva, 2009. 
realizada em dezembro de 2004, em Brasília. $^{24}$

Cumpre destacar também que embora o companheiro supérstite tenha o direito de concorrência na sucessão com descendentes e ascendentes, à semelhança do cônjuge, não terá direito à totalidade da herança, na falta desses herdeiros, pois há a concorrência sucessória com outros parentes sucessíveis (ascendentes e colaterais, esses até o quarto grau) e, portanto, não se situa na terceira posição na ordem de vocação hereditária, recebendo, assim, um tratamento díspar em relação ao conferido ao cônjuge. ${ }^{25}$

Tecidas algumas considerações iniciais acerca do art. 1.790 do Código Civil de 2002, passa-se a ponderar acerca de outros enfoques, no trato específico de situações presentes na realidade social em contraponto com o previsto (ou não) no comentado dispositivo legal, para atribuição da herança ao companheiro.

\subsection{Quais bens podem ser herdados pelo companheiro ou cônjuge (quando casado sob o regime da comunhão parcial de}

\section{bens) em concorrência com os descendentes? Somente os bens particulares? Apenas os bens adquiridos onerosamente? Ou ambos os bens?}

Caso consideremos que $\mathrm{o}$ cônjuge, casado sob o regime da comunhão parcial de bens, na concorrência sucessória com os descendentes do de cujus, possui direito à herança na existência dos bens particulares, e somente quanto a esses bens, iremos vislumbrar uma desigualdade de tratamento no direito sucessório dos cônjuges e dos conviventes, pois o companheiro, embora também recolha a sua meação, fará jus à herança, em concorrência com os descendentes e outros parentes sucessíveis, nos bens comuns, ou seja, nos bens adquiridos onerosamente na constância da união estável.

Dessa forma, caso a interpretação seja literal da letra da lei - quando existir apenas bens adquiridos onerosamente na constância da união -, o companheiro terá um tratamento mais vantajoso que o cônjuge, pois dar-se-á a cumulação dos direitos de herança e meação.

24 Enunciado 266 do Conselho da Justiça Federal: “Aplica-se o inc. I do art. 1.790 também na hipótese de concorrência do companheiro sobrevivente com outros descendentes comuns, e não apenas na concorrência com filhos comuns". Disponível em: $<$ http://www.cjf.gov.br>. Acesso em: 02 abr. 2012.

25 OLIVEIRA, op. cit., p. 159. 
Nas palavras de Euclides de Oliveira $^{26}$, o companheiro "deveria beneficiar-se da herança, [...], apenas sobre os bens particulares do falecido, exatamente como se estabelece em favor do cônjuge sobrevivente”. Para melhor elucidar o seu posicionamento, apresenta o seguinte exemplo:

[...] se o autor da herança deixa um único bem adquirido onerosamente durante a convivência, um herdeiro filho e companheira, esta receberá $50 \%$ do bem pela meação e mais $25 \%$ pela concorrência da herança com o filho. Se o autor da herança fosse casado, nas mesmas condições, o cônjugeviúvo teria direito apenas a $50 \%$ pela meação, restando igual percentagem íntegra para o herdeiro filho.

Conforme Euclides de Oliveira, o tratamento desigual é notório, e se esse não é admitido ao companheiro em outros aspectos, de igual sorte não se sustenta ao cônjuge. Além disso, argumenta que essa atribuição de bens ao companheiro, que já tem a meação, ocasiona na diminuição dos direitos hereditários dos descendentes do autor da herança. ${ }^{27}$

No casamento, com relação ao regime da comunhão parcial de bens, Maria Berenice Dias diz que:
[...] quando o casal se divorcia, são partilhados apenas os bens comuns. Cada um fica com a metade, a título de meação, e com os seus bens particulares. No entanto, se a sociedade conjugal termina pela morte de um dos cônjuges, o outro participa da sucessão como herdeiro. Concorre com os descendentes ou os ascendentes sobre os bens particulares. Ou seja, recebe causa mortis aquilo que não receberia com a extinção inter vivos da sociedade conjugal. $^{28}$

E daí surge uma polêmica nos casos de sucessão do cônjuge em concorrência com descendentes exclusivos do autor da herança; pois caso o autor da herança tenha bens particulares e descendentes fora do casamento, a herança recebida pelo cônjuge sobrevivente não retornará a eles após o seu falecimento, ou seja, parte da herança do ascendente desses descendentes exclusivos que fica com o cônjuge sobrevivente não retorna aos mesmos após o óbito desse antigo herdeiro, acarretando assim desconformidade com o preceituado no ordenamento jurídico, de que a transmissão de bens deve seguir vínculos de parentalidade. ${ }^{29}$

26 OLIVEIRA, op. cit., p. 161.

27 OLIVEIRA, op. cit., p. 162.

28 DIAS, Maria Berenice. Manual das sucessões. São Paulo: Revista dos Tribunais, 2011, p. 158.

29 DIAS, op. cit., p. 158. 
Maria Berenice Dias ${ }^{30}$ esclarece essa situação exemplificando da seguinte forma:

(A) tem dois filhos (C e D) e três imóveis. Resolve casar com (B) pelo regime da comunhão parcial. Quando da morte de (A), em face do direito de concorrência, ao cônjuge sobrevivente (B) caberá um dos imóveis, quota igual ao dos filhos. Vindo a falecer (B), o imóvel que recebeu será transmitido aos seus herdeiros. Se ele não tiver herdeiros, o imóvel é recolhido como herança sem dono e entregue à ente público. Em nenhuma hipótese retorna para (C e D), filhos de (A), que era o seu titular.
Para Maria Berenice Dias, tal situação "evidencia a injustificável quebra do próprio princípio norteador do direito sucessório, que orienta a transmissão patrimonial seguindo os vínculos de parentalidade. ${ }^{31}$

Diante disso, opino que ao cônjuge deve ser garantida, assim como se dá para o companheiro, a participação na herança, exclusivamente, dos bens adquiridos onerosamente na constância do casamento.

No acórdão do Recurso Especial sob n. 1.117.563-SP ${ }^{32}$, a Ministra Nancy Andrighi já se pronunciou a respeito do assunto e decidiu pela

30 DIAS, op. cit., p. 158.

31 Nesse sentido, o Tribunal de Justiça do Rio Grande do Sul decidiu da seguinte forma: AGRAVO DE INSTRUMENTO. SUCESSÃO DE CÔNJUGE SOBREVIVENTE CASADA PELO REGIME DA COMUNHÃO PARCIAL DE BENS. EXISTÊNCIA DE DOIS FILHOS APENAS DO VARÃO, DE RELACIONAMENTO ANTERIOR AO CASAMENTO. Sendo ambígua a redação do art. 1.829, I, existindo diversas correntes em relação ao dispositivo, a melhor interpretação é aquela que entende que o cônjuge sobrevivente deve ser herdeiro apenas dos bens comuns, sendo os bens particulares partilhados apenas entre os descendentes. Interpretação que mais se harmoniza com o regime da comunhão parcial escolhidos pelos cônjuges. Precedente do STJ. Na hipótese dos autos, entretanto, considerando que a decisão determinou a concorrência da viúva com relação aos bens particulares, em atenção à proibição da reformatio in pejus, no presente caso deve ser mantida a partilha também desses bens, afastando-se a regra do art. 1.790 que disciplina a sucessão do(a) companheiro(a) e não se aplica na hipótese. Tratando-se a sub-rogação dos bens e quitação com recursos do FGTS questões de alta indagação, deve ser mantida a remessa às vias ordinárias. RECURSO PARCIALMENTE PROVIDO. (Agravo de Instrumento No 70035286681, Oitava Câmara Cível, Tribunal de Justiça do RS, Relator: Claudir Fidelis Faccenda, Julgado em 20/05/2010.)

32 DIREITO DAS SUCESSÕES. RECURSO ESPECIAL. INVENTÁRIO. DE CUJUS QUE, APÓS O FALECIMENTO DE SUA ESPOSA, COM QUEM TIVERA UMA FILHA, VIVIA, EM UNIÃO ESTÁVEL, HÁ MAIS DE TRINTA ANOS, COM SUA COMPANHEIRA, SEM CONTRAIR MATRIMÔNIO. INCIDÊNCIA, QUANTO À VOCAÇÃO HEREDITÁRIA, DA REGRA DO ART. 1.790 DO CC/02. ALEGAÇÃO, 
PELA FILHA, DE QUE A REGRA É MAIS FAVORÁVEL PARA A CONVIVENTE QUE A NORMA DO ART. 1829, I, DO CC/02, QUE INCIDIRIA CASO O FALECIDO E SUA COMPANHEIRA TIVESSEM SE CASADO PELO REGIME DA COMUNHÃO PARCIAL. AFIRMAÇÃO DE QUE A LEI NÃO PODE PRIVILEGIAR A UNIÃO ESTÁVEL, EM DETRIMENTO DO CASAMENTO.

- O art. 1.790 do CC/02, que regula a sucessão do ‘de cujus’ que vivia em comunhão parcial com sua companheira, estabelece que esta concorre com os filhos daquele na herança, calculada sobre todo o patrimônio adquirido pelo falecido durante a convivência. - A regra do art. 1.829, I, do CC/02, que seria aplicável caso a companheira tivesse se casado com o 'de cujus' pelo regime da comunhão parcial de bens, tem interpretação muito controvertida na doutrina, identificando-se três correntes de pensamento sobre a matéria: (i) a primeira, baseada no Enunciado 270 das Jornadas de Direito Civil, estabelece que a sucessão do cônjuge, pela comunhão parcial, somente se dá na hipótese em que o falecido tenha deixado bens particulares, incidindo apenas sobre esses bens; (ii) a segunda, capitaneada por parte da doutrina, defende que a sucessão na comunhão parcial também ocorre apenas se o 'de cujus' tiver deixado bens particulares, mas incide sobre todo o patrimônio, sem distinção; (iii) a terceira defende que a sucessão do cônjuge, na comunhão parcial, só ocorre se o falecido não tiver deixado bens particulares. - Não é possível dizer, aprioristicamente e com as vistas voltadas apenas para as regras de sucessão, que a união estável possa ser mais vantajosa em algumas hipóteses, porquanto o casamento comporta inúmeros outros benefícios cuja mensuração é difícil.

- É possível encontrar, paralelamente às três linhas de interpretação do art.1.829, I, do CC/02 defendidas pela doutrina, uma quarta linha de interpretação, que toma em consideração a vontade manifestada no momento da celebração do casamento, como norte para a interpretação das regras sucessórias.

- Impositiva a análise do art. 1.829, I, do CC/02, dentro do contexto do sistema jurídico, interpretando o dispositivo em harmonia com os demais que enfeixam a temática, em atenta observância dos princípios e diretrizes teóricas que lhe dão forma, marcadamente, a dignidade da pessoa humana, que se espraia, no plano da livre manifestação da vontade humana, por meio da autonomia privada e da consequente autorresponsabilidade, bem como da confiança legítima, da qual brota a boa-fé; a eticidade, por fim, vem complementar o sustentáculo principiológico que deve delinear os contornos da norma jurídica. - Até o advento da Lei n. 6.515/77 (Lei do Divórcio), vigeu no Direito brasileiro, como regime legal de bens, o da comunhão universal, no qual o cônjuge sobrevivente não concorre à herança, por já lhe ser conferida a meação sobre a totalidade do patrimônio do casal; a partir da vigência da Lei do Divórcio, contudo, o regime legal de bens no casamento passou a ser o da comunhão parcial, o que foi referendado pelo art. 1.640 do CC/02.

- Preserva-se o regime da comunhão parcial de bens, de acordo com o postulado da autodeterminação, ao contemplar o cônjuge sobrevivente com o direito à meação, além da concorrência hereditária sobre os bens comuns, mesmo que haja bens particulares, os quais, em qualquer hipótese, são partilhados apenas entre os descendentes. Recurso especial improvido. (Recurso Especial n ${ }^{\circ}$ 1.117.563-SP, Relatora: Min. Nancy Andrighi, STJ - $3^{\text {a }}$ Turma, Julgado em 17/12/2009.) 
concorrência do cônjuge - com os descendentes - nos bens onerosos, igualando o tratamento dado ao cônjuge e ao companheiro quando há bens adquiridos onerosamente na constância da união.

E, portanto, há de se convir que o tratamento despendido ao cônjuge e ao companheiro sobreviventes será igualitário, nesse aspecto ora em comento, quando àquele for garantido $o$ direito de concorrer com os descendentes nos bens adquiridos onerosamente.

Para Sílvio de Salvo Venosa ${ }^{33}$, o cônjuge sobrevivente só concorre com os descendentes se casado pelo regime da comunhão parcial de bens, diante do fato de existir bens particulares, e nessa hipótese será herdeiro mesmo que exista a meação. Para Eduardo Leite, o cônjuge supérstite, casado pelo regime da comunhão parcial de bens, "será herdeiro somente quando o autor da herança tiver deixado bens particulares, pois nos demais casos o cônjuge será meeiro ou simplesmente tomará sua massa de bens particulares”. Zeno Veloso e Salomão de Araújo Cateb também são a favor de haver concorrência do cônjuge apenas em caso de ha- ver bens particulares, quando casados no regime da comunhão parcial de bens. Por outro lado, para Maria Helena Diniz ${ }^{34}$, há concorrência do cônjuge com os descendentes no que tange aos bens particulares e aos bens onerosos, adquiridos na constância do casamento, pois segundo a mesma não há razão para retirar os bens onerosamente adquiridos durante o casamento

da herança, na concorrência de viúvo com descendente, se, na sua concorrência com ascendente do de cujus, não há qualquer distinção nesse sentido e pouco importará o regime de bens, herdando uma quota em todo o acervo hereditário, que inclui os bens particulares e a metade dos onerosamente adquiridos na constância do matrimônio pelo autor da herança.

Nesse sentido, compartilham da mesma posição os seguintes doutrinadores: Guilherme Calmon da Gama, Inácio de Carvalho Neto, Mario Roberto de Faria, conforme a tabela doutrinária de Francisco Cahali. ${ }^{35} \mathrm{E}$ Maria Berenice Dias, a qual entende que devem comungar apenas os bens onerosos, adquiridos na constância do

33 VENOSA, Sílvio de Salso. Direito civil: direito das sucessões. 8. ed. v. 7. São Paulo: Atlas, 2008, p. 113-114.

34 DINIZ, op. cit., p. 129-135.

35 CAHALI; HIRONAKA, op. cit., p. 189-190. 
casamento; cumprindo ressaltar que a Ministra Nancy Andrighi, ao tratar acerca desse tema, se posicionou nesse mesmo sentido, de que o viúvo deve participar da herança de seu cônjuge falecido, exclusivamente, no que diz respeito aos bens adquiridos onerosamente na constância do casamento. Na minha opinião, esse posicionamento é o que deve prevalecer, pois respeita a escolha do regime de bens pronunciada em vida pelo casal e proclama um tratamento igualitário entre cônjuges e companheiros sobreviventes.

Diante do acima exposto, considera-se interessante salientar que o regime de bens da união estável, de forma geral, segue as regras do regime da comunhão parcial de bens; porém, os conviventes podem estabelecer, por intermédio do pacto antenupcial, um regime de bens diverso desse para se aplicar às suas relações patrimoniais. Caso a escolha seja pelo regime da separação convencional de bens, embora não haja bens comuns, não quer dizer que o direito hereditário do companheiro sobrevivente esteja excluído, pois mesmo que esse regime regulamente a união estável, caso o de cujus tenha adquirido bens onerosamente, o companheiro sobrevivente, apesar de não ser meeiro, exercerá o seu direito hereditário sobre esses bens, a teor do que prescreve o art. 1.790 do Código Civil de $2002 .{ }^{36}$ Ressaltando-se que de igual sorte tal tratamento deve ser garantido ao cônjuge casado sob o regime da separação convencional de bens.

\subsection{O regime da separação obrigatória de bens é aplicado extensivamente aos companheiros?}

O regime da separação de bens, imposto por lei para as pessoas com idade a partir de setenta anos (art. 1.641, II do Código Civil de 2002), não é cabível na união estável, pois se trata de norma restritiva de direito que não pode ser aplicada extensivamente. ${ }^{37}$ Essa norma que limita a escolha do regime de bens no casamento não foi prevista expressamente para os casos de união estável, por isso sua aplicação não pode ser extensiva aos companheiros.

Apesar de ser discutível a aplicação do referido dispositivo até mesmo para o casamento, por ser tal norma

36 VELOSO, op. cit., p. 170.

37 DE FARIAS, Cristiano Chaves; ROSENVALD, Nelson. Direito das famílias. Rio de Janeiro: Lumen Juris, 2008, p. 411. 
considerada inconstitucional, opina Regina Beatriz Tavares da Silva ${ }^{38}$ por uma aplicação sistemática, de que o art. 1.641, II do Código Civil de 2002, aplica-se também às uniões estáveis.

Além disso, é possível encontrar uma deliberação judicial quanto à aplicação extensiva do regime da separação obrigatória de bens em casos de união estável. A $3^{\text {a }}$ Turma do STJ, no REsp 1090722/SP ${ }^{39}$, julgado em 02/03/2010, Rel. Min. Massami Uyeda, decidiu por unanimidade que o disposto no art. 1.641, II do Código

36 VELOSO, op. cit., p. 170.

37 DE FARIAS, Cristiano Chaves; ROSENVALD, Nelson. Direito das famílias. Rio de Janeiro: Lumen Juris, 2008, p. 411.

38 DA SILVA, Regina Beatriz Tavares. Código Civil comentado. 7. ed. São Paulo: Saraiva, 2010, p. 1.738.

39 RECURSO ESPECIAL - UNIÃO ESTÁVEL - APLICAÇÃO DO REGIME DA SEPARAÇÃO OBRIGATÓRIA DE BENS, EM RAZÃO DA SENILIDADE DE UM DOS CONSORTES, CONSTANTE DO ARTIGO 1641, II, DO CÓDIGO CIVIL, À UNIÃO ESTÁVEL - NECESSIDADE - COMPANHEIRO

SUPÉRSTITE - PARTICIPAÇÃO NA SUCESSÃO DO COMPANHEIRO FALECIDO QUANTO AOS BENS ADQUIRIDOS NA CONSTÂNCIA DA UNIÃO ESTÁVEL - OBSERVÂNCIA - INTELIGÊNCIA DO ARTIGO 1790, CC - RECURSO PARCIALMENTE PROVIDO.

I - O artigo 1725 do Código Civil preconiza que, na união estável, o regime de bens vigente é o da comunhão parcial. Contudo, referido preceito legal não encerra um comando absoluto, já que, além de conter inequívoca cláusula restritiva ("no que couber”), permite aos companheiros contratarem, por escrito, de forma diversa; II - A não extensão do regime da separação obrigatória de bens, em razão da senilidade do de cujus, constante do artigo 1641, II, do Código Civil, à união estável equivaleria, em tais situações, ao desestímulo ao casamento, o que, certamente, discrepa da finalidade arraigada no ordenamento jurídico nacional, o qual se propõe a facilitar a convolação da união estável em casamento, e não o contrário; III - Ressalte-se, contudo, que a aplicação de tal regime deve inequivocamente sofrer a contemporização do Enunciado n. 377/STF, pois os bens adquiridos na constância, no caso, da união estável, devem comunicar-se, independente da prova de que tais bens são provenientes do esforço comum, já que a solidariedade, inerente à vida comum do casal, por si só, é fator contributivo para a aquisição dos frutos na constância de tal convivência; IV - Excluída a meação, nos termos postos na presente decisão, a companheira supérstite participará da sucessão do companheiro falecido em relação aos bens adquiridos onerosamente na constância da convivência (período que não se inicia com a declaração judicial que reconhece a união estável, mas, sim, com a efetiva convivência), em concorrência com os outros parentes sucessíveis (inciso III, do artigo 1790, CC). V - Recurso parcialmente provido. (Recurso Especial no 1090722-SP, Relator: Min. Massami Uyeda, STJ - $3^{\mathrm{a}}$ Turma, Julgado em 02/03/2010.) 
Civil, deve ser estendido aos casos de união estável, embora com a ressalva de que os bens adquiridos na constância da união estável devem comunicar-se, sem a necessidade de prova do esforço comum. Dessa forma, é possível vislumbrar a aplicação da Súmula 377 do $\mathrm{STF}^{40}$ - que, na minha opinião, permanece em vigor - extensivamente à união estável.

40 Na vigência do Código Civil de 1916, o Supremo Tribunal Federal editou a Súmula 377, cujo verbete possui os seguintes termos: "No regime da separação legal de bens, comunicam-se os adquiridos na constância do casamento”. Com ela o regime da separação legal de bens passou a constituir um autêntico "regime de separação parcial de bens”, em que o patrimônio adquirido na constância do casamento passaria a se comunicar (BATISTA, Thales Pontes. Regime da Separação de Bens: Estudo da recepção ou não da Súmula 377 do STF à luz do novo Código Civil. In: Âmbito Jurídico. Rio Grande, 63, 01/04/2009. p. 01. Disponível em: <http://www.ambito-juridico.com.br/ site/?n_link=revista_artigos_leitura\&artigo_id=5899\&revista_ caderno $=14>$. Acesso em: 09 jun. 2011.) Com a edição do atual Código Civil, passou-se a discutir sobre a validade ou não da referida súmula, não havendo consenso entre os doutrinadores acerca da sua aplicação. Para Francisco Cahali, a Súmula 377 do STF está superada, uma vez que não há incidência de seu comando no novo regramento (o art. 259 do CC de 16 não foi reproduzido no CC de 2002), não se admitindo a prevalência dos princípios da comunhão parcial em relação aos bens adquiridos durante o casamento sobre o regime de separação obrigatória (CAHALI, F. J. A Súmula n. 377 e o novo Código Civil e a Mutabilidade do Regime de Bens. Revista do Advogado da AASP - Associação dos Advogados de São Paulo, São Paulo, 2004, p. 27-32.) Entretanto, há quem entenda que referida súmula deva ser aplicada. Nesse contexto, de controvérsias doutrinárias, de um lado há a tendência apresentada no novo Código Civil para a preservação da pureza do regime da separação legal de bens, em razão de não ter sido mantido o art. 259 do CC de 16; e de outro, a tentativa de evitar o enriquecimento ilícito de um dos cônjuges, ao assegurar a partilha dos bens adquiridos, mediante efetiva participação de ambos, na constância do relacionamento. Por derradeiro, conclui-se que a Súmula 377 permanece em vigor, tendo o cônjuge supérstite direito à meação dos bens adquiridos na constância do casamento, pois caso considere-se pela inaplicabilidade da súmula ora em comento, o cônjuge não terá direito à concorrência sucessória com os descendentes e tampouco terá direito à meação. Nas palavras de Zeno Veloso (VELOSO. op. cit., p. 55), “[...] embora o cônjuge sobrevivente não concorra com os descendentes se o regime é o da separação obrigatória, pode pleitear a meação dos bens adquiridos com o esforço comum após o casamento”. Conforme Zeno Veloso (VELOSO, Zeno. op. cit., p. 55), opinam de igual forma pela aplicabilidade da Súmula 377 do STF após a edição do Código Civil de 2002, dentre outros, os seguintes doutrinadores: Maria Helena Diniz, Maria Berenice Dias, Paulo Lôbo, Rolf Madaleno, Paulo Nader. 


\subsection{Da concorrência sucessória do companheiro com descen- dentes do autor da herança}

Primeiramente, cumpre esclarecer que na realidade o atual legislador civil pretendeu dar distinto tratamento à sucessão do companheiro em concorrência com os herdeiros de primeira vocação, ou seja, com os descendentes ${ }^{41}$, aplicando diferentes imposições matemáticas que fazem o companheiro sobrevivente herdar a mesma porção deferida aos filhos comuns e metade da porção cabível aos descendentes exclusivos do autor da herança. ${ }^{42}$

Visto isso, passa-se à análise da participação do companheiro, na sucessão do de cujus, que possui con- dições legais de concorrência com os descendentes, veja-se:

\subsubsection{Da concorrência} sucessória do companheiro com

\section{filhos comuns}

Se o companheiro concorrer com filhos comuns (filhos do companheiro supérstite e do de cujus), terá direito a uma quota equivalente à que por lei for atribuída ao filho (art. 1.790, I, do Código Civil). Não há na sucessão do companheiro a mesma regra assegurada ao cônjuge, no art. 1.832 do Código Civil de 2002, quanto à quota mínima de uma quarta parte da herança, se for ascendente dos herdeiros com que concorrer.

Orlando Gomes, na sua obra atualizada por Mario Roberto Carvalho de

41 EMBARGOS INFRINGENTES. SUCESSÕES. INVENTÁRIO. ANULAÇÃO DE ATO JURÍDICO. RECONHECIMENTO DO COMPANHEIRO SOBREVIVENTE COMO HERDEIRO, EM CONCORRÊNCIA COM O DESCENDENTE. SUCESSÃO DO COMPANHEIRO À LUZ DO CÓDIGO CIVIL VIGENTE. CONSTITUCIONALIDADE DA REGRA PREVISTA NO ARTIGO 1.790 E INCISOS DO CÓDIGO CIVIL, QUE CONFERE TRATAMENTO DIFERENCIADO AO COMPANHEIRO E AO CÔNJUGE. Em razão do julgamento de improcedência no colendo Órgão Especial deste Tribunal, da Arguição de Inconstitucionalidade n. ${ }^{\circ} 70029390374$, reconhecendo a constitucionalidade do art. 1.790, III, do Código Civil, por aplicação do disposto no art. 211 do RITJRGS há que se reconhecer a aplicabilidade do art. 1.790, CC/02, inclusive relativamente ao inciso II, incidente no caso concreto. EMBARGOS INFRINGENTES ACOLHIDOS, POR MAIORIA. (Embargos Infringentes No 70032120735, Quarto Grupo de Câmaras Cíveis, Tribunal de Justiça do RS, Relator: Rui Portanova, Julgado em 12/03/2010.)

42 HIRONAKA, Giselda Maria Fernandes Novaes. Posição Sucessória do companheiro (membro da união de facto/união estável) nos direitos brasileiros e português. In: Escritos de direito das famílias: uma perspectiva luso brasileira. p. 439. Coordenação: DIAS, Maria Berenice; PINHEIRO, Jorge Duarte (Coord.). Porto Alegre: Magister Editora, 2008,. p. 432-450. 
Faria ${ }^{43}$, constata que se há concorrência do companheiro com filhos comuns, a sucessão se dá por cabeça, repartindo-se a herança em partes iguais, em tantas partes quantos forem os herdeiros.

Questão exemplificativa: como fica a partilha de bens no caso do falecido, que possuía $\mathrm{R} \$ 100.000,00$ em bens particulares, e que deixou dois filhos comuns e uma companheira, com a qual construiu o patrimônio comum de R\$200.000,00? A companheira receberá a meação no valor de $\mathrm{R} \$ 100.000,00$ e, concorrentemente com os dois filhos comuns, herdará a quota equivalente aos mesmos na herança de $\mathrm{R} \$ 100.000,00$ (antiga "meação" do de cujus), ou seja, cada um ficará com 33,33\% (100/3 = 33,33) da herança. Além disso, cada filho herdará sua quota-parte (50\%) quanto aos bens particulares, que montam em R \$ 100.000,00, ou seja, cada filho herdará mais R \$50.000,00.

Dessa forma, os filhos receberão 83,33\% (50 + 33,33) da herança; e a companheira ficará com 133,33\% (100 referente à meação e 33,33 com relação à herança).
Por outro lado, convém dizer que opino pela igualdade de tratamento do cônjuge e do companheiro em todos os aspectos do direito das sucessões; portanto, considero que a quota mínima de uma quarta parte da herança deve ser garantida ao companheiro se esse for ascendente dos herdeiros com que concorrer.

\subsubsection{Da concorrência} sucessória do companheiro com descendentes exclusivos

Caso venha o companheiro sobrevivente concorrer com descendentes só do autor da herança, tocar-lhe-á a metade do que couber a cada um daqueles (art. 1.790, II, do Código Civil de 2002)..$^{44}$ Ao passo que se o cônjuge supérstite concorrer com descendentes exclusivos receberá a mesma quota-parte da herança cabível por lei aos descendentes (art. 1.832 do Código Civil de 2002). ${ }^{45}$

Conforme Giselda Hironaka ${ }^{46}$, na concorrência sucessória do companheiro com descendentes exclusivos do autor da herança: do ponto de vista prático, a partilha se faz na proporção

43 GOMES, Orlando. Sucessões. Atual. por Mario Roberto Carvalho de Faria. 14. ed. Rio de Janeiro: Forense, 2007, p. 67.

44 DINIZ, op. cit., p. 142.

45 Art. 1.832 do Código Civil de 2002. Em concorrência com os descendentes (art. 1.829, inciso I) caberá ao cônjuge quinhão igual ao dos que sucederem por cabeça, não podendo a sua quota ser inferior à quarta parte da herança, se for ascendente dos herdeiros com que concorrer.

46 HIRONAKA, 2008, op. cit., p. 439. 
de dois para um, ou seja, entrega-se uma parte da herança ao convivente supérstite, enquanto cada um dos descendentes recebe duas partes idênticas àquela entregue ao companheiro.

Francisco Cahali ${ }^{47}$ salienta o fato de que a lei não distingue entre os chamados por cabeça daqueles chamados por representação; porém, apenas se mostra lógica a previsão se destinar ao companheiro sobrevivo a metade do que os descendentes por cabeça herdarem, diretamente ou representando herdeiro premorto.

Questão exemplificativa: como fica a partilha de bens no caso do falecido, que deixou dois filhos exclusivos e uma companheira, com a qual construiu o patrimônio comum de R\$ 200.000,00?

Diante do fato de que o companheiro que sobrevive deve ficar com $50 \%$ (metade) do que couber a cada filho, deve-se atentar ao fato de que cada filho recebe dois e a companheira recebe um. Primeiramente, soma-se os convocados por cabeça, multiplica-se o número de filhos por dois e depois soma-se a parcela do que sobreviveu. Assim, 2 (filhos) x $2=4+1$ (companheiro sobrevivente) $=5 ; 100.000,00$ (herança) $/ 5=20.000,00 .{ }^{48}$ Portanto, ela recebe $R \$ 20.000,00(1 / 5)$ e cada filho o dobro, ou seja, $\mathrm{R} \$ 40.000,00$ (2/5). As quotas-partes dos filhos somadas montam em $\mathrm{R} \$ 80.000,00$, que acrescidas à quota do convivente supérstite de $\mathrm{R} \$ 20.000,00$ alcançam a totalidade da herança, qual seja de R\$ 100.000,00. Ressalta-se, por fim, que a companheira, nesse caso, receberá ainda a sua meação no valor de $\mathrm{R} \$$ $100.000,00 .{ }^{49}$

Entretanto, considera-se importante dizer que ao companheiro deveria ser garantido o direito de receber a mesma quota-parte da herança cabível por lei aos descendentes exclusivos do autor da herança, ou seja, a concorrência do companheiro com os descendentes exclusivos deveria se dar nos moldes da concorrência desses com o cônjuge.

\subsubsection{Da concorrência sucessória do companheiro com filiação híbrida}

Uma das problemáticas que se apresenta na norma prevista no art. 1.790 do Código Civil está no que toca à lacuna da lei, que não estabelece como deve ocorrer a sucessão do

47 CAHALI; HIRONAKA, op. cit., p. 184.

48 Utiliza-se a seguinte fórmula: $2 \mathrm{x}+\mathrm{y}=$ denominador. $\mathrm{O}$ valor da herança deverá ser dividido pelo denominador e o resultado será a parte cabível à companheira, assim como o referido valor em dobro será a parte cabível a cada filho.

49 Nesse sentido, CAHALI; HIRONAKA, op. cit., p. 184. 
convivente sobrevivo quando concorre, conjuntamente, tanto com os descendentes exclusivos como com os comuns, ou seja, quando está diante de um caso de sucessão híbrida. ${ }^{50}$

Com o intuito de apresentar uma discussão que gire em torno desse impasse, proponho a apresentação de algumas correntes doutrinárias fundamentais acerca do tema:

- A corrente majoritária preceitua que em caso de sucessão híbrida deve-se aplicar por analogia o art. 1.790, I, do Código Civil, ou seja, deve-se tratar todos os descendentes como filhos co- muns, e promover uma divisão igualitária entre a companheira e os filhos do de cujus. ${ }^{51} \mathrm{~A}$ crítica a essa corrente diz que "não se atingiria o objetivo legal pretendido, por prejudicar os filhos exclusivos do de cujus que nenhum laço de parentesco consanguíneo têm com o companheiro sobrevivente, privilegiado na partilha", ${ }^{2}$

- Uma segunda corrente doutrinária吕 dispõe acerca da aplicação, por analogia, do art. 1.790, II, do Código Civil. Segundo Maria Helena Diniz ${ }^{54}$, ante a omissão da lei aplica-se o art.

50 Expressão cunhada por Giselda Hironaka.

51 CAHALI; HIRONAKA. op. cit., p. 191-192. Na tabela doutrinária de Cahali, filiam-se a esse entendimento os seguintes doutrinadores: Caio Mário da Silva Pereira, Christiano Cassettari, Francisco José Cahali, Maria Berenice Dias, Maria Helena Daneluzzi, Guilherme Calmon Nogueira da Gama, Inácio de Carvalho Neto, Jorge Shiguemitsu Fujita, José Fernando Simão, Luiz Paulo Vieira de Carvalho, Mario Delgado, Rodrigo da Cunha Pereira, Rolf Madaleno e Sílvio de Salvo Venosa.

De acordo com Carlos Roberto Gonçalves (GONÇALVES, Carlos Roberto. Direito civil brasileiro: direito das sucessões. 4. ed. v. 7. São Paulo: Saraiva, 2010, p. 196.): “da mesma forma que só foi assegurado ao cônjuge sobrevivente a reserva da quarta parte da herança quando todos os descendentes com os quais concorresse fossem comuns, o privilégio assegurado aos descendentes do companheiro falecido, de receberem o dobro do quinhão que couber ao companheiro sobrevivente, só é assegurado, [...] quando inexistirem descendentes comuns”. E nesse sentido opina Mário Luiz Delgado Régis.

52 DINIZ, op. cit., p. 146-147.

53 De acordo com Flávio Tartuce, filiam-se a essa corrente os seguintes doutrinadores: Maria Helena Diniz, Flávio Tartuce, Gustavo René Nicolau, Sebastião Amorim, Euclides de Oliveira e Zeno Veloso (TARTUCE, Flávio. Da sucessão do companheiro. O polêmico art 1.790 do CC e suas controvérsias principais. Disponível em: <http:// www.flaviotartuce.adv.br/index2.php?sec=artigos $>$. Acesso em: 10 maio 2011.)

54 DINIZ, op. cit., p. 143. 
$4^{\circ}$ e $5^{\circ}$ da Lei de Introdução às Normas do Direito Brasileiro, a fim de imperar a igualdade jurídica de todos os filhos, disposta no art. 227, §6 da Constituição da República, importando apenas o vínculo de filiação com o autor da herança, e não o que existe com o convivente sobrevivente, que terá direito à metade do que couber a cada um dos descendentes do de cujus. Portanto, para essa corrente, todos os descendentes "serão considerados como filhos exclusivos do falecido para fins de direito sucessório, tendo o companheiro sobrevivente direito à metade do que couber a cada um deles". ${ }^{55}$ A crítica contra essa corrente diz que o companheiro sobrevivente resta lesado, pois estaria recebendo menos por ser tido como não ascendente de nenhum dos herdeiros. ${ }^{56}$
- Uma terceira corrente prescreve a aplicação por analogia do art. 1.790, III do Código Civil, na qual se filia Mário Roberto Carvalho de Faria. ${ }^{57}$

- Uma quarta corrente determina que se deve aplicar uma fórmula matemática de ponderação para solução da problemática ${ }^{58}$, ressalvado o disposto no art. 1.834 do Código Civil, o qual dispõe que "os descendentes da mesma classe têm os mesmos direitos à sucessão de seus ascendentes”.

- E, por fim, há ainda o entendimento que pressupõe a aplicação conjunta do art. 1.790, incisos I e II do Código Civil, que confere ao companheiro sobrevivente uma quota em concorrência com os filhos comuns e meia quota em concorrência com os descendentes exclusivos do autor da herança. Entretanto, caso fosse aplicado tal argumento, os descendentes sairiam

55 DINIZ, op. cit., p. 147.

56 DINIZ, op. cit., p. 147.

57 CAHALI; HIRONAKA, op. cit., p. 191-192. Conforme sua tabela doutrinária.

58 Dentre algumas fórmulas citamos a Fórmula de Tusa. Conforme ponderações realizadas por Maria Helena Diniz: “Gabriele Tusa entende que, para se estabelecer a média ponderada, seria preciso multiplicar o número de filhos comuns por 1 e o de filhos exclusivos por 0,5 . Somados os dois resultados, divide-se pelo número total de filhos. O resultado é o coeficiente de quanto o convivente herdaria em relação aos filhos do de cujus". Nesse caso, os filhos herdarão o mesmo quinhão e o companheiro herdará quinhão menor ao deles (DINIZ. op. cit., p. 147). 
perdendo, pois cada um receberia uma quota única e o companheiro ficaria com o quinhão maior equivalente a uma quota e meia. ${ }^{59}$

A meu ver, respeitadas as opiniões em contrário, a melhor solução, caso exista a filiação híbrida em concorrência com o companheiro, é efetuar a "divisão igualitária dos quinhões hereditários”, ou seja, aplica-se o art. 1.790, I, do Código Civil de 2002, afastando o direito dos descendentes exclusivos de receber a quota-parte da herança em dobro do que couber ao companheiro sobrevivente. ${ }^{60}$

Esse posicionamento possui sua razão de ser no fato de que se deve dar tratamento igualitário entre o companheiro e o cônjuge, na hipótese de filiação híbrida.

\subsection{Da concorrência sucessória do companheiro com outros parentes sucessíveis}

Ao dar continuidade ao estudo da sucessão do companheiro, é possível verificar que o art. 1.790, III, do Código Civil, dispõe que se o convivente supérstite concorrer com outros parentes sucessíveis, terá direito a um terço da herança.

Com outros parentes sucessíveis, leia-se os ascendentes e os colaterais até o quarto grau. E há quem entenda pela inconstitucionalidade de referido dispositivo legal. ${ }^{61}$ Convindo ressaltar

59 DINIZ, op. cit., p. 147.

60 GONÇALVES, op. cit., p. 196.

61 Nesse sentido: AGRAVO DE INSTRUMENTO. INVENTÁRIO. COMPANHEIRO SOBREVIVENTE. DIREITO À TOTALIDADE DA HERANÇA. PARENTES COLATERAIS. EXCLUSÃO DOS IRMÃOS DA SUCESSÃO. INAPLICABILIDADE DO ART. 1790, INC. III, DO CC/02. INCIDENTE DE INCONSTITUCIONALIDADE. ART. 480 DO CPC. Não se aplica a regra contida no art. 1790, inc. III, do CC/02, por afronta aos princípios constitucionais da dignidade da pessoa humana e de igualdade, já que o art. 226, § $3^{\circ}$, da CF, deu tratamento paritário ao instituto da união estável em relação ao casamento. Assim, devem ser excluídos da sucessão os parentes colaterais, tendo o companheiro o direito à totalidade da herança. Incidente de inconstitucionalidade arguido, de ofício, na forma do art. 480 do CPC. Incidente rejeitado, por maioria. Recurso desprovido, por maioria”. (TJRS, Agravo de Instrumento N. 70017169335, Porto Alegre, Oitava Câmara Cível, Rel. Des. José Ataídes Siqueira Trindade, julgado em 08/03/2007.). Concluindo do mesmo modo: TJSP, Agravo de instrumento n. 654.999.4/7, Acórdão n. 4034200, São Paulo, Quarta Câmara de Direito Privado, Rel. Des. Teixeira Leite, julgado em 27/08/2009, DJESP 23/09/2009 e TJSP, Agravo de instrumento n. 609.024.4/4, Acórdão n. 3618121, São Paulo, Oitava Câmara de Direito Privado, Rel. Des. Caetano Lagrasta, julgado em 06/05/2009, DJESP 17/06/2009. 
que o nosso Tribunal posicionou-se pela constitucionalidade do art. 1.790, III, do Código Civil. ${ }^{62}$
Ao analisarmos outros parentes sucessíveis deveríamos considerar apenas os ascendentes. E no que tange

O Tribunal de Justiça do Rio Grande do Sul já decidiu nesse sentido, ou seja, pela inconstitucionalidade desse dispositivo legal, veja-se: EMBARGOS INFRINGENTES. UNIÃO ESTÁVEL. SUCESSÃO. COMPANHEIRA SOBREVIVENTE. DIREITO À TOTALIDADE DA HERANÇA. EXCLUSÃO DOS COLATERAIS. INAPLICABILIDADE DO ART. 1.790, INC. III, DO CÓDIGO CIVIL. Tendo a Constituição Federal, em seu art. 226, § $3^{\circ}$, equiparado a união estável ao casamento, o disposto no art. 1.790, III, do Código Civil vigente colide com a norma constitucional prevista, afrontando princípios da dignidade da pessoa humana e da igualdade, resguardados na Carta Constitucional, razão para ser negado vigência ao disposto legal. À união estável são garantidos os mesmos direitos inerentes ao casamento, efeito que se estende ao plano sucessório, mormente no caso em exame onde autora e "de cujus" viveram more uxorio por três décadas, obtendo o reconhecimento judicial desta união como estável aos fins da C.F. Inexistindo descendentes e ascendentes, é da companheira sobrevivente o direito à totalidade da herança, excluindo-se os parentes colaterais. EMBARGOS INFRINGENTES ACOLHIDOS. SUSCITADO INCIDENTE DE RESERVA DE PLENÁRIO. (SEGREDO DE JUSTIÇA) Embargos Infringentes $N^{\circ} 70027265545$, Quarto Grupo de Câmaras Cíveis, Tribunal de Justiça do RS, Relator: André Luiz Planella Villarinho, Julgado em 10/07/2009.

62 INCIDENTE DE INCONSTITUCIONALIDADE. FAMÍLIA. UNIÃO ESTÁVEL. SUCESSÃO. A Constituição da República não equiparou a união estável ao casamento. Atento à distinção constitucional, o Código Civil dispensou tratamento diverso ao casamento e à união estável. Segundo o Código Civil, o companheiro não é herdeiro necessário. Aliás, nem todo cônjuge sobrevivente é herdeiro. O direito sucessório do companheiro está disciplinado no art. 1790 do CC, cujo inciso III não é inconstitucional. Trata-se de regra criada pelo legislador ordinário no exercício do poder constitucional de disciplina das relações jurídicas patrimoniais decorrentes de união estável. Eventual antinomia com o art. 1725 do Código Civil não leva a sua inconstitucionalidade, devendo ser solvida à luz dos critérios de interpretação do conjunto das normas que regulam a união estável. INCIDENTE DE INCONSTITUCIONALIDADE JULGADO IMPROCEDENTE, POR MAIORIA. (Incidente de Inconstitucionalidade $\mathrm{N}^{\circ} 70029390374$, Tribunal Pleno, Tribunal de Justiça do RS, Relator: Leo Lima, Julgado em 09/11/2009). Atualmente, o entendimento do Tribunal de Justiça do Rio Grande do Sul é o seguinte: COMPANHEIRO SOBREVIVENTE. EXISTÊNCIA DE COLATERAIS. NÃO AFASTAMENTO DA REGRA DO ARTIGO 1.790, III, DO CÓDIGO CIVIL. DISPOSITIVO DECLARADO CONSTITUCIONAL PELO ÓRGÃO ESPECIAL DO TRIBUNAL. Não é inconstitucional o artigo 1.790, III, do Código Civil, ao dispor que o (a) companheiro (a), concorrendo com outros parentes sucessíveis do companheiro, terá direito a um terço da herança, quanto aos bens adquiridos onerosamente na vigência da união estável. Regula a sucessão e a legitimação para suceder a lei vigente ao 
à concorrência com os ascendentes ${ }^{63}$, não há o que se discutir, pelo menos por ora, quanto à destinação de um terço da herança ao companheiro.

Porém, quanto à concorrência deste com os colaterais, considero que deveria operar-se tal como na sucessão do cônjuge, ou seja, na falta de descendentes, ascendentes e convivente, chama-se a suceder os colaterais até quarto grau; atendendo-se ao princípio de que os mais próximos excluem os mais remotos. Portanto, na existência de companheiro sobre- vivente, excluído deveria estar o colateral da sucessão do autor da herança.

A concorrência do companheiro com os colaterais descumpre um preceito essencial e fundamental do Direito das Sucessões que é a ordem de vocação hereditária prevista no art. 1.829 do Código Civil de 2002. Além disso, a aplicação do art. 1.790, III do Código Civil de 2002, desconsidera o companheiro como um herdeiro necessário. E diante do fato de que o cônjuge e o companheiro são iguais perante o direito patrimonial, não ha-

tempo da abertura daquela. Aplicação do artigo 1.787, do Código Civil. RECURSO PROVIDO. (SEGREDO DE JUSTIÇA) (Agravo de Instrumento $N^{\circ} 70032581530$, Oitava Câmara Cível, Tribunal de Justiça do RS, Relator: Claudir Fidelis Faccenda, Julgado em 17/12/2009).

Considera-se interessante trazer ainda ao estudo a decisão do STJ que decidiu pelo afastamento dos colaterais, no caso da sucessão ser aberta antes do Código Civil de 2002. Veja-se: CIVIL E PROCESSUAL CIVIL. INVENTÁRIO. UNIÃO ESTÁVEL. RECONHECIMENTO SUPERVENIENTE. INCIDÊNCIA DO ART. 462 DO CPC. POSSIBILIDADE. ART. $2^{\circ}$, INCISO III, DA LEI N. ${ }^{\circ}$ 8.971/94. AUSÊNCIA DE ASCENDENTES E DESCENDENTES DO DE CUJUS. COMPANHEIRO. TOTALIDADE DA HERANÇA.

1. O art. 462 do CPC permite, tanto ao Juízo singular como ao Tribunal, a análise de circunstâncias outras que, devido a sua implementação tardia, não eram passíveis de resenha inicial. 2. Tal diretriz deve ser observada no âmbito do Superior Tribunal de Justiça, porquanto o art. 462 não possui aplicação restrita às instâncias ordinárias, conforme precedentes da Casa. 3. Havendo reconhecimento de união estável e inexistência de ascendentes ou descendentes do falecido, à sucessão aberta em 28.02.2000, antes do Código Civil de 2002, aplica-se o disposto no art. $2^{\circ}$, inciso III, da Lei n. ${ }^{\circ} 8.971 / 94$, circunstância que garante ao companheiro a totalidade da herança e afasta a participação de colaterais do de cujus no inventário. 4. Recurso especial conhecido e provido. (Recurso Especial n 704637-RJ, Relator: Min. Luis Felipe Salomão, STJ - $4^{\mathrm{a}}$ Turma, Julgado em 17/03/2011).

63 Ressalta-se que a sucessão do ascendente se dará pelo lado paterno e/ou pelo lado materno, não havendo direito de representação em caso de ascendente já falecido. Existindo pai ou mãe do de cujus, os avós ou bisavós, independentemente se paternos ou maternos, não herdam em concorrência com o companheiro sobrevivente. 
vendo descendentes ou ascendentes, ao companheiro deve-lhe tocar a totalidade da herança.

\subsection{Da totalidade da herança na sucessão do companheiro}

O convivente supérstite terá direito à totalidade da herança, caso não possua o de cujus parentes sucessíveis, conforme preconiza o art. 1.790 , IV do Código Civil.

Cumpre ressaltar ainda a existência de uma polêmica envolvendo a exegese da expressão "totalidade da herança”, escrita no inciso IV do art. 1.790 do Código Civil. Tendo em vista que através dela surge o seguinte questionamento: essa "totalidade" diria respeito, de um lado, somente aos bens adquiridos onerosamente durante a união estável, ou, de outro lado, abrangeria também os bens anteriores à existência dessa união, assim como aqueles adquiridos na constância do relacionamento a título gratuito ou com cláusula de incomunicabilidade?

Pois bem, acredito que a aplicação da segunda hipótese seria a mais correta, pois o legislador estabelece, no art. 1.819 do Código Civil de 2002, que se caracteriza como jacente a herança, somente em caso de alguém falecer sem deixar testamento ou herdeiro legítimo, como, por exemplo, o companheiro sobrevivente.

Caso assim não fosse, os bens deixados por um companheiro falecido, que não consistissem naqueles adquiridos a título oneroso durante a união estável, na hipótese de inexistência de descendentes, ascendentes ou parentes colaterais do de cujus, seriam destinados, absurdamente, ao Município, ou ao Distrito Federal ou à União, na qualidade de herança jacente, e não ao companheiro sobrevivo.

\subsection{Quando o companheiro falecido possui apenas bens adquiridos antes de iniciar a convivência (bens particulares), ou depois, a título gratuito}

De acordo com alguns doutrinadores, a restrição da incidência do direito hereditário do companheiro sobrevivente aos bens onerosamente adquiridos na constância da união estável pode gerar consequências injustas em alguns casos. E para melhor esclarecer, ilustra-se tal situação com o exemplo apresentado por Zeno Veloso: ${ }^{64}$

A companheira de muitos anos de um homem rico, que possuía vários bens na época que iniciou o

64 VELOSO, op. cit., p. 173. 
relacionamento afetivo, não herdará coisa alguma do companheiro se este não adquiriu (onerosamente!) outros bens durante o tempo da convivência. Ficará essa mulher - se for pobre literalmente desamparada, a não ser que o falecido, vencendo as superstições que rodeiam o assunto, tivesse feito um testamento que a beneficiasse.

Em razão disso, questiona-se: Para quem serão destinados tais bens particulares e os adquiridos a título gratuito, se o autor da herança deixou apenas o companheiro sem ter descendentes, ascendentes ou parentes sobrevivos? Para o Município ou para o companheiro? ${ }^{65}$

Há entendimentos de que os bens seriam do Poder Público, aplicado o art. $1.844^{66} \mathrm{c} / \mathrm{c}$ o art. 1.790 do CC, ou seja, se o companheiro possui direito a herdar somente os bens adquiridos onerosamente, então não há que se falar em herança dos bens adquiridos particularmente pelo de cujus. ${ }^{67}$
Por outro lado, há quem entenda que o destino de tais bens seja ao companheiro sobrevivente, em razão do art. 1.844 do Código Civil de 2002 ser claro ao dispor que: "Não sobrevivendo cônjuge, ou companheiro, nem parente algum sucessível, ou tendo eles renunciado a herança, esta se devolve ao Município ou ao Distrito Federal, se localizada nas respectivas circunscrições, ou à União, quando situada em território federal”.

$\mathrm{O}$ que me parece fazer mais sentido, pois o dispositivo legal acima transcrito prescreve que serão transmitidos ao Município, Distrito Federal ou União, respeitadas as peculiaridades de cada caso, quando não sobreviver cônjuge, companheiro ou alguma parente sucessível.

A herança vacante surgirá apenas quando não deixar o autor da herança herdeiro ou sucessor regular. O Poder Público não poderá se beneficiar dos bens do de cujus quando existir companheiro sobrevivente, pois seria

65 CAHALI; HIRONAKA, op . cit., p. 191-192. Conforme a tabela doutrinária de Francisco Cahali, consideram que deve haver concorrência do companheiro com o Poder Público os seguintes doutrinadores: Francisco José Cahali, Giselda Hironaka, Inácio de Carvalho Neto, Maria Helena Daneluzzi, Mário Delgado, Rodrigo da Cunha Pereira. Por outro lado, consideram indevida tal concorrência: Caio Mario da Silva Pereira, Christiano Cassetari, Eduardo de Oliveira Leite, Maria Berenice Dias, Maria Helena Diniz, Rolf Madaleno, Sílvio de Salvo Venosa, entre outros.

66 Art. 1.844 do Código Civil de 2002. Não sobrevivendo cônjuge, ou companheiro, nem parente algum sucessível, ou tendo eles renunciado a herança, esta se devolve ao Município ou ao Distrito Federal, se localizada nas respectivas circunscrições, ou à União, quando situada em território federal.

67 DINIZ, op. cit., p. 143. Essa é a posição de Zeno Veloso, por exemplo. 
injusto dar preferência àquele do que a este, que teve vínculos afetivos. ${ }^{68}$

De acordo com Maria Helena Diniz: ${ }^{69}$

[...] o companheiro receberá a totalidade da herança, no que atina aos adquiridos onerosa e gratuitamente antes ou durante a união estável, recebendo, portanto, todos os bens do de cujus, que não irão ao Município, Distrito Federal ou à União, por força no disposto no art. 1.844, $1^{\text {a }}$ parte, do Código Civil de 2002, que é uma norma especial (relativa à herança vacante), sobrepondo-se ao art. 1.790, IV (norma geral sobre sucessão do companheiro). ${ }^{70}$

\subsection{Da concorrência sucessória entre o companheiro e o cônjuge separado de fato}

O Código Civil de 2002 permite que o cônjuge separado de fato possa constituir união estável, conforme consagra o seu art. 1.723, § $1^{\circ}$. Em razão disso, não é de surpreender o fato de existir em nossa sociedade, por exemplo, um homem separado de fato que convive em união estável com outra mulher.

Caso estejamos diante de uma situação dessas, quem irá herdar os bens? A esposa com quem mantém o vínculo matrimonial, ou a companheira com quem convivia? ${ }^{71}$

Para responder tais questionamentos, adoto o entendimento de Flávio Tartuce ${ }^{72}$, de que a separação de fato põe fim ao regime de bens, portanto o patrimônio deve ser dividido em dois montes. Um composto pelos bens adquiridos na constância do casamento e outro pelos bens adquiridos onerosamente no decorrer da união estável. Onde a cônjuge será herdeira dos bens adquiridos no decorrer do casamento, enquanto a companheira será herdeira dos bens adquiridos onerosamente na constância da união estável.

Por outro lado, é possível dizer que, para que o monte-mor seja dividido em dois montes, a separação de fato deverá ser superior a dois anos, conforme preceitua o art. 1.830 do Código Civil. Para Maria Helena Diniz: ${ }^{73}$

68 DINIZ, op. cit., p. 144.

69 DINIZ, op. cit., p. 144.

70 Nesse sentido também opina Zeno Veloso, seguindo uma nova interpretação (VELOSO. op. cit., p. 185).

71 TARTUCE. op. cit., p. 10.

72 TARTUCE, op. cit., p. 10.

73 DINIZ, op. cit., p. 117-118. 
[...] não está descartada a hipótese de um separado de fato vir a constituir, antes do lapso temporal de dois anos, uma união estável e com seu óbito dar origem a um conflito sucessório, possibilitando, se amealhou bem durante o estado convivencial, a concorrência entre cônjuge e convivente com descendentes do de cujus.

Conforme o art. 1.830 do Código Civil, se o cônjuge supérstite estiver separado há mais de dois anos do de cujus, não haverá direito à herança dos bens adquiridos posteriormente à separação, salvo se provar que a separação não se deu por sua culpa. Porém, não há razões para prosperar a sucessão entre cônjuges separados, visto que à época da morte não há convivência e tampouco afetividade. ${ }^{74}$

\subsection{Do direito ao usufruto vidual do companheiro}

O direito ao usufruto vidual do companheiro sobrevivente permanece em vigor, pois a Lei n. 8.971/94 que prevê referido direito hereditário ao convivente supérstite não restou revogada pelo Código Civil de 2002.
Dessa forma, embora tal direito não permaneça garantido ao cônjuge sobrevivo, enquanto as leis que tratam da união estável não são revogadas, o companheiro sobrevivente possui assegurado o direito ao usufruto vidual.

Assim, assegura-se ainda ao companheiro sobrevivente em concurso com descendentes ou ascendentes do de cujus a participação na herança mediante o direito de usufruto, respectivamente, em um quarto ou metade dos bens. ${ }^{75}$

Por fim, convém salientar que opino pelo tratamento igualitário do cônjuge e do companheiro sobrevivos; razão pela qual considero que o usufruto vidual - assim como deixou de ser garantido ao cônjuge - deve deixar de ser assegurado ao companheiro, com a revogação da Lei n. 8.971/94.

\subsection{Do direito real de habitação para o companheiro sobrevivente}

O companheiro sobrevivente também terá assegurado o direito real de habitação ${ }^{76}$, enquanto viver ou não

74 DINIZ, op. cit., p. 118.

75 Art. $2^{\circ}$, I e II da Lei n. 8.971/94.

76 CAHALI; HIRONAKA, op. cit., p. 191-192. Conforme a tabela doutrinária de Cahali, entendem como devido ao companheiro o direito real de habitação os seguintes doutrinadores: Christiano Cassetari, Giselda Hironaka, Guilherme Calmon Nogueira 
constituir nova união ou casamento, relativamente ao imóvel destinado à residência da família. ${ }^{77}$

Porém, referido direito restou garantido, expressamente, no Código Civil de 2002, somente ao cônjuge, silenciando com relação a sua aplicação também aos companheiros.

Para alguns doutrinadores, como Mário Luiz Delgado e Zeno Veloso, o legislador excluiu intencionalmente esse direito dos companheiros, ao passo que não deve ser realizada nenhuma analogia, posto que inexiste qualquer lacuna acerca disso. ${ }^{78}$

Por outro lado, para Diniz deve-se aplicar por analogia o disposto no art. $1.831^{79}$ do Código Civil em busca do justo, atendendo-se o direito à moradia. ${ }^{80}$

Por derradeiro, entendo que o direito real de habitação deve ser garantido aos companheiros pelo fato de que a Lei 9.278/96 continua em vigor; não há revogação expressa dos dispositivos previstos nessa legislação, e como o Código Civil de 2002 não prevê acerca da totalidade dos direi-

da Gama, Gustavo René Nicolau, Maria Berenice Dias, Maria Helena Diniz, Maria Helena Daneluzzi, Rolf Madaleno, Sílvio de Salvo Venosa, Zeno Veloso e outros.

77 Enunciado n. 117 do CJF/STJ, aprovado na I Jornada de Direito Civil de 2002: “o direito real de habitação deve ser estendido ao companheiro, seja por não ter sido revogada a previsão da Lei n. 9.278/96, seja em razão da interpretação analógica do art. 1.831, informado pelo art. $6^{\circ}$, caput, da CF/88”. Disponível em:<http://www.cjf. gov.br>. Acesso em: 02 abr. 2012.

78 DINIZ. op. cit., p. 148-149.

79 Art. 1.831 do Código Civil de 2002. Ao cônjuge sobrevivente, qualquer que seja o regime de bens, será assegurado, sem prejuízo da participação que lhe caiba na herança, o direito real de habitação relativamente ao imóvel destinado à residência da família, desde que seja o único daquela natureza a inventariar.

80 DINIZ, op. cit., p. 150. Nesse sentido, temos a seguinte jurisprudência: APELAÇÃO CÍVEL. AÇÃO REIVINDICATÓRIA. REQUISITOS. TÍTULO HÁBIL A DEMONSTRAR O DOMÍNIO E POSSE INJUSTA DO RÉU. DIREITO REAL DE HABITAÇÃO DA COMPANHEIRA. DECLARAÇÃO DE VOTO. Ainda que exibido o título de domínio pela A., por força do exercício do direito sucessório, não restou caracterizada a posse injusta da R., que permaneceu residindo no imóvel em face da união estável mantida com o genitor da A., questão incontroversa nos autos. Incide, no caso, o parágrafo único do art. $7^{\circ}$ da Lei 9.278/96, que garante o direito real de habitação ao companheiro sobrevivente, enquanto não constituída nova união ou casamento. NEGADO PROVIMENTO À APELAÇÃO. UNÂNIME. TRIBUNAL DE JUSTIÇA DO RIO GRANDE DO SUL. Apelação Cível N 70021146980, Décima Oitava Câmara Cível, Tribunal de Justiça do RS, Relator: Nara Leonor Castro Garcia, Julgado em 20/11/2008. 
tos hereditários dos companheiros, de igual forma, não há revogação tácita.

Com a revogação dessa lei extravagante, conclui-se que tal benefício deve ser garantido ao companheiro nos mesmos termos que deveria ser concedido ao cônjuge, ou seja, que o direito real de habitação seja assegurado ao cônjuge e ao companheiro, relativamente ao imóvel destinado a residência da família, sem qualquer restrição de que deva ser esse o único bem daquela natureza a inventariar ${ }^{81}$, e desde que permaneça o estado de viuvez.

\subsection{Da inconstitucionalidade do art. 1.790 do Código Civil}

Uma das teses que sustentam a suposta inconstitucionalidade de todo o art. 1.790 é quanto ao desprezo da equalização do companheiro ao cônjuge, dada pela Constituição da República em seu art. $226, \S 3^{\circ}{ }^{82}$

Por outro lado, para Francisco Cahalii ${ }^{83}$, a Constituição da República apenas institucionalizou a relação concubinária pura, formada por pessoas que embora podendo se casar preferiram manter uma união livre de formalismo, passando a denominá-la de união estável, elevando-a à categoria de entidade familiar a ser protegida pelo Estado; pois, para o direito sucessório, não houve equiparação da união estável ao casamento, tendo em vista que "não se conferiu ao companheiro, pelo só texto constitucional, a vocação hereditária diante do falecimento do outro, como se casado fosse". E essa é a tese de quem debate a constitucionalidade do referido dispositivo. ${ }^{84}$

\section{Conforme o PL n. 7583/2010.}

82 Tese de titularidade defendida pela autora na Universidade de São Paulo, em setembro de 2010: HIRONAKA, Giselda Maria Fernandes Novaes. Morrer e suceder. Passado e presente da transmissão sucessória concorrente. São Paulo, 2010, p. 447-457.

83 CAHALI; HIRONAKA. op. cit., p. 177.

84 Nesse sentido, pode-se verificar as seguintes decisões: A Constituição Federal não equiparou o instituto da união estável ao do casamento, tendo tão somente reconhecido aquele como entidade familiar (art. 226, $\S 3^{\circ}, \mathrm{CF}$ ). Dessa forma, é possível verificar que a legislação civil buscou resguardar, de forma especial, o direito do cônjuge, o qual possui prerrogativas que não são asseguradas ao companheiro. Sendo assim, o tratamento diferenciado dado pelo Código Civil a esses institutos, especialmente no tocante ao direito sobre a participação na herança do companheiro ou cônjuge falecido, não ofende o princípio da isonomia, mesmo que, em determinados casos, como o dos presentes autos, possa parecer que o companheiro tenha sido privilegiado. O artigo 1.790 do Código Civil, portanto, é constitucional, pois não fere o princípio da isonomia. (TJDF, Recurso n. 2009.00.2.001862-2, Acórdão n. 355.492, Primeira Turma Cível, Rel. Des. Natanael 
Ressaltando-se que sou favorável à tese de inconstitucionalidade apenas no que tange à possibilidade do companheiro concorrer com os colaterais até o quarto grau na sucessão de seu convivente falecido, conforme o inciso III do art. 1.790 do Código Civil, por ser, nesse caso, realmente, desprestigiada a união estável.

\subsection{Do projeto de lei n. 7.583 de 2010}

O projeto de lei n. 7.583 está apensado ao projeto de lei n. 6.025 de 2005 e propõe a alteração das Leis n. 10.406, de 10 de janeiro de 2002 (Código Civil), e n. 5.869, de 11 de janeiro de 1973 (Código de Processo Civil), e

Caetano, DJDFTE 12/05/2009, p. 81. UNIÃO ESTÁVEL. SUCESSÃO DO COMPANHEIRO. DIFERENÇA DE TRATO LEGISLATIVO ENTRE UNIÃO ESTÁVEL E CASAMENTO. INEXISTÊNCIA DE VIOLAÇÃO A PRECEITOS OU PRINCÍPIOS CONSTITUCIONAIS. 1. A capacidade sucessória é estabelecida pela lei vigente no momento da abertura da sucessão. Inteligência do art. 1.787 do Código Civil. 2. O art. 226 da Constituição Federal não equiparou a união estável ao casamento civil, apenas admitiu-lhe a dignidade de constituir entidade familiar, para o fim de merecer especial proteção do Estado, mas com a expressa recomendação de que seja facilitada a sua conversão em casamento. 3. Tratando-se de institutos jurídicos distintos, é juridicamente cabível que a união estável tenha disciplina sucessória distinta do casamento e, aliás, é isso o que ocorre, também, com o próprio casamento, considerando-se que as diversas possibilidades de escolha do regime matrimonial de bens também ensejam sequelas jurídicas distintas. 4. O legislador civil tratou de acatar a liberdade de escolha das pessoas, cada qual podendo escolher o rumo da sua própria vida, isto é, podendo ficar solteira ou constituir família, e, pretendendo constituir uma família, a pessoa pode manter uma união estável ou casar, e, casando ou mantendo união estável, a pessoa pode escolher o regime de bens que melhor lhe aprouver. Mas cada escolha evidentemente gera suas próprias sequelas jurídicas, produzindo efeitos, também, no plano sucessório, pois pode se submeter à sucessão legal ou optar por fazer uma deixa testamentária. 5. É possível questionar que a regulamentação do direito sucessório no Código Civil vigente talvez não seja a melhor, ou que a regulamentação posta na Lei n. 9.278/96 talvez fosse a mais adequada, mas são discussões relevantes apenas no plano acadêmico ou doutrinário, pois existe uma lei regulando a matéria, e essa lei não padece de qualquer vício, tendo sido submetida a regular processo legislativo, sendo devidamente aprovada, e, como existe lei regulando a questão, ela deve ser cumprida, já que se vive num Estado democrático de direito. Embargos infringentes desacolhidos, por maioria. (Embargos Infringentes No 70038442166, Quarto Grupo de Câmaras Cíveis, Tribunal de Justiça do RS, Relator: Sérgio Fernando de Vasconcellos Chaves, Julgado em 08/10/2010.) 
a revogação das Leis $\mathrm{n}^{\circ}$ 8.971, de 29 de dezembro de 1994, e $\mathrm{n}^{\circ} 9.278$, de 10 de maio de 1996, para assegurar a ampliação dos direitos civis dos companheiros na união estável.

A proposta de alteração no Código Civil de 2002 se dá nos seguintes termos:

Os arts. 1.829, 1.830, 1.831, 1.832, 1.834, 1.837, 1.838 e 1.839 do Código Civil de 2002 passam a vigorar com a seguinte redação:

Art. 1.829.

I - aos descendentes, em concorrência com o companheiro ou cônjuge sobrevivente, salvo se casado este com o falecido no regime da comunhão universal, ou no da separação obrigatória de bens (art. 1.641); ou se, no regime da comunhão parcial, o autor da herança não houver deixado bens particulares;

II - aos ascendentes, em concorrência com o cônjuge ou com o companheiro sobrevivente;

III - ao cônjuge ou companheiro sobrevivente;

Art. 1.830. Somente é reconhecido direito sucessório ao cônjuge ou ao companheiro sobrevivente se, ao tempo da morte do outro, não estavam separados judicialmente, nem separados de fato há mais de dois anos. (NR)

Art. 1.831. Ao cônjuge ou ao companheiro sobrevivente, qualquer que seja o regime de bens, será assegurado, sem prejuízo da participação que lhe caiba na herança, o direito real de habitação relativamente ao imóvel destinado à residência da família, desde que, na abertura da sucessão esteja na posse exclusiva do falecido e do sobrevivente ou somente do sobrevivente. (NR)

Art. 1.832. Em concorrência com os descendentes (art. 1.829, inciso I) caberá ao cônjuge ou ao companheiro sobrevivente quinhão igual ao dos que sucederem por cabeça, não podendo a sua quota ser inferior à quarta parte da herança, se for ascendente dos herdeiros com que concorrer. (NR)

Art. 1.834. Os descendentes de mesmo grau, qualquer que seja a origem do parentesco têm os mesmos direitos à sucessão de seus ascendentes. (NR)

Art. 1.837. Concorrendo com ascendente em primeiro grau, ao cônjuge ou companheiro sobrevivente tocará um terço da herança; caberlhe-á a metade desta se houver um só ascendente, ou se maior for aquele grau. (NR)

Art. 1.838. Na falta de descendentes e ascendentes, será deferida a sucessão por inteiro ao cônjuge ou ao companheiro sobrevivente. (NR)

Art. 1.839. Se não houver cônjuge ou companheiro sobrevivente, nas condições estabelecidas no art. 1.830 , serão chamados a suceder os colaterais até o quarto grau. (NR) Revoga-se o art. 1.790 do Código Civil de 2002.

Com relação às leis n. 8.971 de 1994 e n. 9.278 , de 10 de maio de 1996, o referido projeto de lei propõe a revogação expressamente. Veja-se:

Revogam-se [...] as Leis n. 8.971, de 29 de dezembro de 1994, e n. 9.278, de 10 de maio de 1996. 


\section{CONSIDERAÇÕES FINAIS}

Na realidade, estamos distante de uma clareza legal, doutrinária e jurisprudencial acerca da sucessão decorrente da união estável. A variação de posicionamentos e entendimentos acerca do tema proposto ao estudo nada mais é do que o reflexo do sistema caótico que enfrentamos no Brasil quanto à sucessão do companheiro sobrevivente.

Diante da forma pela qual esse instituto é disciplinado no ordenamento jurídico brasileiro, é possível, que em alguns casos, enseje-se injustiças, e para isso ser evitado é necessária a análise apurada de cada caso atentando aos princípios e às diretrizes da Constituição da República. ${ }^{85}$

Nos dizeres de Carlos José de Castro Costa: "Não obstante a adequação de todos os ramos do direito civil à perspectiva constitucional, $\mathrm{o}$ direito sucessório, em contramão, ainda não sofre os reflexos dos valores inseridos pela Constituição Federal. Ainda não se visualiza na sucessão mortis causa um objetivo de promoção da pessoa humana, na sua real e concreta dimensão". E para endossar sua opinião, conclui que no direito sucessório os valores existenciais ainda são os direitos patrimoniais, vistos sob o prisma do individualismo, pois o objetivo continua a ser a transmissão da riqueza, sem a promoção da dignidade da pessoa. ${ }^{86}$

Por derradeiro, com o fito de tornar o mundo jurídico mais justo, enquanto não sobrevém o preenchimento das lacunas do direito sucessório, seguimos fazendo colmatações embasadas nos princípios constitucionais que norteiam esse ramo do Direito. Cumprindo à doutrina e à jurisprudência apresentar-se condizente com a funcionalização do direito patrimonial em prol da realização da pessoa humana, combinada com a efetivação da ideia de função social, preconizada pela Constituição da República.

\section{REFERÊNCIAS}

BATISTA, Thales Pontes. Regime da separação de bens: estudo da recepção ou não da súmula 377 do
STF à luz do novo código civil. Âmbito Jurídico. Rio Grande, 63, 01/04/2009. p. 01. Disponível

85 COSTA, Carlos José de Castro. Sucessão do cônjuge à luz da Constituição Federal. Revista brasileira de direito das famílias e sucessões. v. 14. Porto Alegre: Magister, fev./mar. 2010. p. 28.

86 COSTA, op. cit., p. 28-29. 
em: <http://www.ambito-juridico. com.br/site/?n_link=revista_ artigos_leitura\&artigo_ id $=5899 \&$ revista_caderno $=14>$. Acesso em: 09 jun. 2011.

BRASIL. Código Civil. Lei n. 3.071 de $1^{\circ}$ de janeiro de 1916. Disponível em: <http://www.planalto.gov.br/ ccivil/leis/L3071.htm> Acesso em: 04 abr. 2012.

. Código Civil. Lei n. 10.046, de 10 de janeiro de 2002. Disponível em: <http://www. planalto.gov.br/ccivil/leis/2002/ L10406.htm>. Acesso em: 04 abr. 2012.

Constituição da República Federativa do Brasil de 1988. Disponível em: <http://www.planalto.gov.br/ccivil_03/constituicao/constitui\%C3\%A7ao.htm> Acesso em: 02 abr. 2012.

- Lei n. 8.971, de 29 de dezembro de 1994. Disponível em: <http://www.planalto.gov. br/ccivil_03/leis/L8971.htm> Acesso em: 04 de abr. 2012.

. Lei n. 9.278, de 10 de maio de 1996. Disponível em: <http:// www.planalto.gov.br/ccivil_03/ leis/19278.htm> Acesso em: 04 de abr. 2012.

- Projeto de Lei n. 7.583 de 2010. Disponível em: $<$ http://www.camara.gov.br/ proposicoesWeb/fichadetramitaca o? idProposicao $=482478>$ Acesso em: 04 de abr. 2012.
CAHALI, F. J. A Súmula n. 377 e o novo Código Civil e a Mutabilidade do Regime de Bens. Revista do Advogado da AASP - Associação dos Advogados de São Paulo, São Paulo, 2004, p. 27-32.

CAHALI, Francisco José; HIRONAKA, Giselda Maria Fernandes Novaes. Curso avançado de direito civil. 3. ed. São Paulo: Editora Revista dos Tribunais, 2007.

COSTA, Carlos José de Castro. Sucessão do Cônjuge à luz da Constituição Federal. Revista brasileira de direito das famílias e sucessões. v. 14. Porto Alegre: Magister, fev./mar. 2010.

DA SILVA, Regina Beatriz Tavares. Código civil comentado. 7. ed. São Paulo: Saraiva, 2010.

DE FARIAS, Cristiano Chaves; ROSENVALD, Nelson. Direito das famílias. Rio de Janeiro: Lumen Juris, 2008.

DIAS, Maria Berenice. Manual das sucessões. São Paulo: Revista dos Tribunais, 2011.

DINIZ, Maria Helena. Curso de direito civil brasileiro: direito das sucessões. 21. ed. rev. e atual. de acordo com a reforma do CPC. v. 6. São Paulo: Saraiva, 2007.

Curso de direito civil brasileiro: direito das sucessões. 23. ed. Reformulada. v. 6. São Paulo: Editora Saraiva, 2009.

FERRIANE, Luciana de Paula Assis. Sucessão do companheiro. São Paulo: Editora Saraiva, 2010. 
GOMES, Orlando. Direito de família. 12. ed. rev. e atual. por Humberto Theodoro Júnior. Rio de Janeiro: Forense, 2000.

. Sucessões. atual. por Mario Roberto Carvalho de Faria. 14. ed. Rio de Janeiro: Forense, 2007. GONÇALVES, Carlos Roberto. Direito civil brasileiro: direito das sucessões. 4. ed. v. 7. São Paulo: Saraiva, 2010.

HIRONAKA, Giselda Maria Fernandes Novaes. Morrer e suceder. passado e Presente da transmissão sucessória concorrente. São Paulo, 2010, p. 447-457.

Posição Sucessória do companheiro (membro da união de facto /união estável) nos direitos brasileiros e português. In: Escritos de direito das famílias: uma perspectiva luso brasileira. DIAS, Maria Berenice; PINHEIRO, Jorge Duarte. Porto Alegre: Magister Editora, 2008, p. 432-450.

KÜMPEL, Vitor. Concubinato impuro. São Paulo: Complexo Jurídico Damásio de Jesus, jul. 2001. Disponível em: <www.damasio. com.br/novo/html/frame_artigos. htm>. Acesso em: 09 jun. 2011.
NORONHA, Carlos Silveira. Reflexões doutrinárias acerca do direito das sucessões. In: NORONHA, Carlos Silveira (Org.). As novas perspectivas do direito das sucessões em tempos de modernidade e pós-modernidade. Porto Alegre: Sulina, 2011.

OLIVEIRA, Euclides. Direito de herança. A nova ordem da sucessão. 2. ed. São Paulo: Saraiva, 2009.

PONTES DE MIRANDA. Tratado de direito privado, Parte Especial, TOMO LV. Direito das sucessões: sucessão em geral. Sucessão legítima. 3. ed. Rio de Janeiro: Editora Borsoi, 1972. § 5.614, capítulo 2.

TARTUCE, Flávio. Da sucessão do companheiro. $O$ polemico art. 1.790 do CC e suas controvérsias principais. Disponível em: $<$ http://www.flaviotartuce.adv.br/ index2.php?sec=artigos $>$. Acesso em: 10 maio 2011.

VELOSO, Zeno. Direito hereditário do cônjuge e do companheiro. São Paulo: Editora Saraiva, 2010. VENOSA, Sílvio de Salso. Direito civil: direito das sucessões. 8. ed. v. 7. São Paulo: Atlas, 2008. 